\title{
南海北部末次冰期以来深水沉积物组成及其 堆积速率的时空变化特征
}

\author{
赵绍华, 刘志飞*, 陈全, 王星星, 施江南, 金海燕, 刘晶晶, 翦知涽 \\ 同济大学海洋地质国家重点实验室, 上海 200092 \\ *通讯作者, E-mail: 1zhifei@tongji.edu.cn
}

收稿日期: 2017-02-16; 接受日期: 2017-05-19; 网络版发表日期: 2017-06-15

国家自然科学基金项目(批准号: 91528304, 41530964, 91428310, 41525020)资助

\begin{abstract}
摘要通过对南海北部深水断面上MD12-3428(水深903m)、MD12-3433(水深2125m)和MD12-3434(水深2995m) 三个岩芯的沉积物成分及其堆积速率分析, 研究末次冰期以来南海深水沉积物组成和堆积速率的时空变化特征 及其控制因素. 研究结果显示, 南海北部末次冰期以来的深水沉积物主要由陆源碎屑(59 89\%)和碳酸盐(6 38\%) 组成, 并含有少量蛋白石 (1.6 9.4\%)和有机质 (0.7 1.9\%). 陆源碎屑和碳酸盐的堆积速率分别达到2.4 21.8和 0.4 $6.5 \mathrm{~g} \mathrm{~cm}^{-2} \mathrm{ka}^{-1}$ 范围, 比蛋白石和有机质堆积速率高出 $1 \sim 2$ 个数量级. 在末次冰期以来的时间序列变化上, 沉 积物各成分含量及其堆积速率都具有冰期-间冰期的旋回变化, 陆源碎屑、蛋白石和有机质的含量及其堆积速 率在氧同位素 2 期显著增加, 而碳酸盐的含量及其堆积速率则呈反向变化或增幅不明显, 表明南海深水碳酸盐 含量在低海平面时期受到陆源碎屑稀释的影响. 在从陆坡向深海盆的空间变化上, 陆源碎屑的含量在同时期随 水深的增加而增加, 但其堆积速率锐减; 碳酸盐含量及其堆积速率则随水深的增加而递减; 而有机质和蛋白石 的含量及其堆积速率随水深增加呈现复杂的变化特征. 本文研究认为, 南海北部末次冰期以来深水沉积物的组 成及其堆积速率受到海平面变化的强烈控制, 季风降雨引起的陆源物质供给、海洋初级生产力、以及陆源碎 屑和海洋生源物质的相互稀释作用, 共同影响了南海深水沉积物的堆积过程.
\end{abstract}

关键词沉积物成分, 堆积速率, 时空变化, 未次冰期, 海平面变化, 南海

\section{1 引言}

深海是地球表层最晚被认知的部分, 深海过程研 究是当今国际海洋研究的焦点和前沿领域之一, 可能 成为地球系统科学的突破口(汪品先, 2009, 2012). 南 海是西太平洋地区最大的边缘海, 位于最大的大陆(亚 洲)和最大的大洋(太平洋)之间, 具有开展深海研究的
一系列优越性. 南海周边陆地及岛屿是全球表层陆 地风化剥蚀作用最强、剥蚀速率最大的地区, 强烈的 季风降雨使得河流系统非常发育, 每年向南海输入约 $1600 \mathrm{Mt}$ 的陆源悬移物质,约占世界总量 $8.4 \%$, 成为世 界上接受陆源物质最多的封闭或半封闭海盆(Milliman 和Farnsworth, 2011; Liu等, 2016). 这些巨量的陆源物 质在从源到汇的搬运和沉积过程中, 受到东亚季风引

中文引用格式: 赵绍华, 刘志飞, 陈全, 王星星, 施江南, 金海燕, 刘晶晶, 翦知淐. 2017. 南海北部末次冰期以来深水沉积物组成及其堆积速率的时空变化 特征. 中国科学: 地球科学, 47: 958-971, doi: 10.1360/N072016-00276

英文引用格式： Zhao S H, Liu Z F, Chen Q, Wang X X, Shi J N, Jin H Y, Liu J J, Jian Z M. Spatiotemporal variations of deep-sea sediment components and their fluxes since the last glaciation in the northern South China Sea. Science China Earth Sciences, 60: 1368-1381, doi: 10.1007/s11430-016-9058-6 
起的物质供给和洋流活动等过程的影响(Liu等, 2010a, 2016; Zhang等, 2015; Zhao等, 2015); 同时, 其携带的丰 富营养盐又引起海洋初级生产力的勃发(Liu等, 2002; Ning等, 2004; Chen, 2005). 因此, 南海的深海沉积物在 堆积过程中蕴藏了大量有关陆地、海洋、生命及其相 互作用的信息, 为进行构造演化、古海洋以及古季风 演化等研究提供了良好的材料(Wang等, 2000, 2014), 使南海成为研究深海过程及地球系统演变的天然实 验室.

过去 20 多年中, 共有 20 个国际科学考察航次在南 海先后完成, 获得了 200 多个高质量岩芯, 提供了时长 达 $33 \mathrm{Ma}$ 的连续深海沉积序列, 在深海过程、古海洋演 化以及东亚古季风变迁等方面的研究, 取得了一系列 重要科研成果(Wang等, 1995, 1999, 2014, 2016; Wang L 等, 1999; Clift等, 2014). 然而, 前人对于深海沉积物基 本成分组成及堆积过程的研究还不够全面, 以往多侧 重于一种或几种成分含量的时间序列变化, 如陆源碎 屑的矿物成分(Liu等, 2003, 2010b; Boulay等, 2005)、 碳酸盐(Wang等, 1995; Chen等, 2003)和有机质等(Chen 等, 2003; 李丽等, 2008), 整体上涉及到沉积物各成分 堆积速率的研究还比较少见(李建如等, 2002; 王汝建 和李建, 2003; 王汝建等, 2007; Wan等, 2007, 2010). 特 别地, 在末次冰期, 与深海沉积过程有关的东亚季风、 古生产力变化等各项研究均相对成熟, 但对于深海沉 积物的基本成分组成及其堆积速率却仍然没有获得 明确的认识, 仅有少量研究估算了冰期-间冰期尺度上 的沉积物堆积速率及总量(Schönfeld和Kudrass, 1993; 黄维和汪品先, 1998, 2007; 章伟艳等, 2002), 造成对南 海深海沉积过程及其环境响应认知上的偏颇. 因此, 本项研究利用南海北部陆坡深水断面上水深依次相 差约 $1000 \mathrm{~m}$ 的三个沉积岩芯, 系统地开展沉积物主要 成分分析, 结合沉积物干样密度测试, 研究南海北部 末次冰期以来深水沉积物组成及其堆积速率的时空 变化特征, 进而详细探讨深海沉积物的堆积过程及其 主要控制因素.

\section{2 材料与方法}

为了获得南海北部深海沉积物成分及堆积速率的 时空变化信息, 本文选择陆坡断面上水深相差约 $1000 \mathrm{~m}$ 的三个高质量 CASQ(Calypso Square-Cores)沉积岩

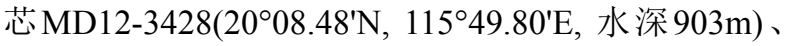
$\mathrm{MD} 12-3433\left(19^{\circ} 16.88^{\prime} \mathrm{N}, 116^{\circ} 14.52^{\prime} \mathrm{E}\right.$, 水深 $\left.2125 \mathrm{~m}\right)$ 和 MD12-3434(18 49.84' $\mathrm{N}, 116^{\circ} 18.89^{\prime} \mathrm{E}$, 水深 $\left.2995 \mathrm{~m}\right)$ 为研 究材料. 三个岩芯长度则分别为 $10.15 、 8.20$ 和 $8.33 \mathrm{~m}$, 均位于南海北部珠江峡谷东侧(图1), 由2012年实施 的中法合作航次“MD190-CIRCEA”(Circulation in East Asian Seas)使用“Marion-Dufresne”科考船所采集. 岩 芯沉积物为均匀连续且无明显扰动的泥质或者粉砂 质沉积, 代表了南海北部正常海洋环境的稳定沉积 记录(Kissel等, 2012). 陆坡上部MD12-3428岩芯由均 一的灰色粘土质粉砂组成, 偶见破碎贝壳; 陆坡中 部MD12-3433 岩芯和下部MD12-3434岩芯则由浅灰 色-深灰色粘土组成, 有机质含量相对较高. 为了测 试岩芯沉积物干样密度及堆积速率, 样品采集使用 $16.40 \mathrm{~mm} \times 16.40 \mathrm{~mm} \times 16.88 \mathrm{~mm}$ 的近立方体塑料盒, 采 样分辨率为 $20 \mathrm{~cm}$, 三个岩芯分析依次获得 $51 、 41$ 和

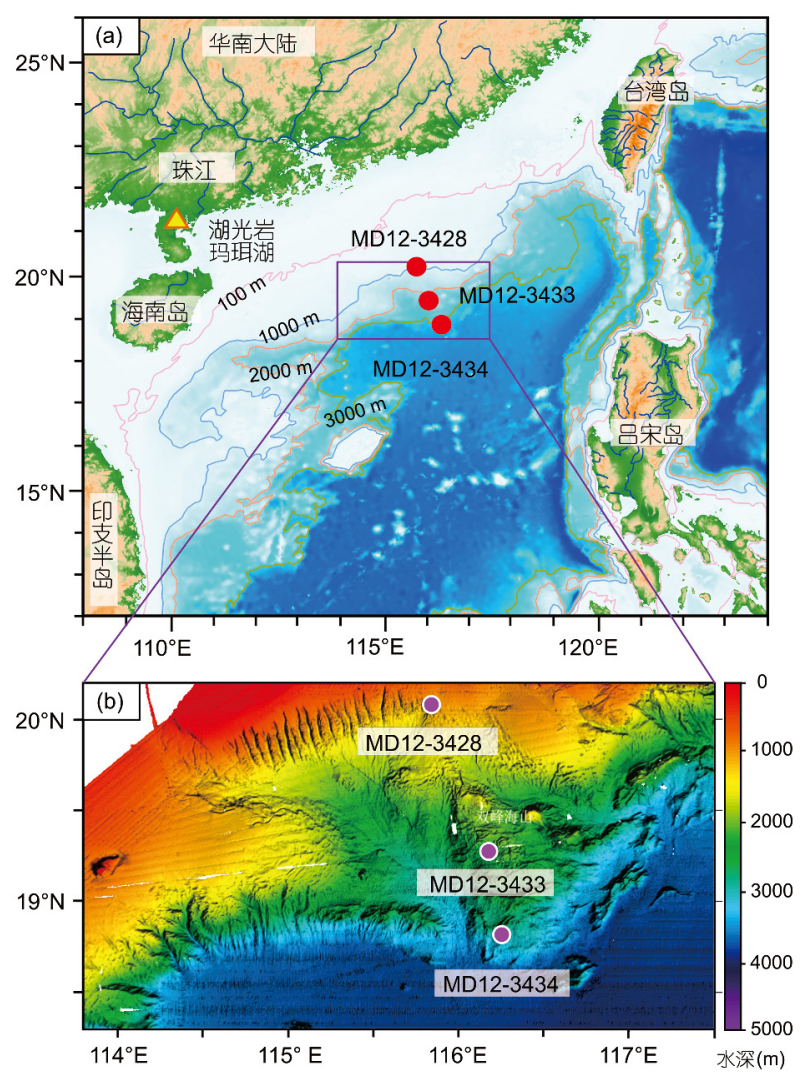

图 1 研究站位及其附近海域高分辨地形地貌 (a) 研究岩芯分布图, MD12-3428、MD12-3433和MD12-3434三个岩 芯沿着1000 3000m的水深断面分布; (b) 研究站位附近高分辨地形 地貌图, 底图据Ding等(2013) 
42 个样品, 共计 134 个.

海洋沉积物一般由陆源碎屑和生源颗粒以及海 洋自生矿物组成, 生源颗粒主要包括碳酸盐、蛋白石 和有机质, 三者百分比含量均可由实验分析获得. 一 般地, 末次冰期以来海底近表层的自生矿物较少, 与 陆源输入相比, 可忽略不计. 因此, 本文采用的深海沉 积物主要成分包括陆源碎屑、碳酸盐、蛋白石和有 机质。陆源碎屑的含量由 $100 \%$ 依次减去各生源颗粒 百分含量获得, 即: 陆源碎屑 $\%=100 \%$ - 碳酸盐 $\%$-蛋白 石 $\%$ - 有机质 $\%$. 同时, 利用沉积物干样密度数据 $(D B D$, Dry Bulk Density, 单位: $\mathrm{g} \mathrm{cm}^{-3}$ ), 结合研究岩芯的沉积 速率 ( $S R$, Sedimentation Rate, 单位: $\mathrm{cm} \mathrm{ka}^{-1}$ ), 根据Rea 和Janecek(1981)的方法可以计算出沉积物总堆积速率 ( $M A R$, Mass Accumulation Rate, 单位: $\mathrm{g} \mathrm{cm}^{-2} \mathrm{ka}^{-1}$ ), 公式 为

$$
M A R=S R \times D B D .
$$

最后, 把沉积物各成分百分含量分别乘以 $M A R$, 即 可得到沉积物各成分的堆积速率, 公式为

$$
X-A R=M A R \times X \%,
$$

$X$ 为陆源碎屑、碳酸盐、蛋白石或者有机质. 所有样 品的实验分析均在同济大学海洋地质国家重点实验 室完成.

沉积物干样密度是指单位体积内沉积物原位湿 样完全烘干后的重量, 样品分析使用立方体小盒采 满的原位沉积物湿样. 首先把样品盒外表洗净, 用 铝箔纸包裹, 留出一丝缝隙, 置于 $-80^{\circ} \mathrm{C}$ 冰柜中冷冻 $12 \mathrm{~h}$. 然后将冷冻好的样品放置于冷干机内, $72 \mathrm{~h}$ 后取 出, 除去外表铝箔, 称重得到质量 $M 1$. 取出样品盒中 的沉积物样品, 转入样品袋存放在干燥器血中. 样品 盒洗净、烘干后称重得到质量 $M 2$, 测量样品盒内侧 长、宽和高依次记为 $a 、 b$ 和 $c$. 最后计算 $D B D$, 公式为 $D B D=(M 1-M 2) /(a \times b \times c)$.

碳酸盐含量分析采用气体测定法, 即通过测量样 品中碳酸盐和盐酸反应放出的 $\mathrm{CO}_{2}$ 的体积, 计算碳酸 盐含量. 首先取适量烘干的样品研磨成粉, 准确称取 $(0.1000 \pm 0.0010) \mathrm{g}$, 和装有 $1: 3$ 盐酸溶液的小试管一起放 入反应容器, 拧紧测量气压装置. 然后倾斜轻摇使盐 酸与碳酸盐充分反应, 记录气压表读数后, 清洗干净 待测下一个样品. 由于所使用气压表已经过线性标定, 即 $0.1000 \mathrm{~g}$ 的标准碳酸钻样品与过量盐酸反应生成的
$\mathrm{CO}_{2}$ 产生的气压标定为 1.000 (即 $100 \%$ ). 因此, 沉积物 样品的碳酸盐含量可以直接从气压表中读出.

沉积物有机质含量分析使用德国Elementar有机元 素分析仪Vario EL CUBE, 仪器分析标准偏差 $\leq 0.1 \%$, 精 度 $\leq 0.2 \%$. 取约 $0.5 \mathrm{~g}$ 烘干的样品研磨成粉末, 转入 $50 \mathrm{~mL}$ 离心管, 加 $10 \mathrm{~mL}$ 的 $1 \mathrm{~mol} \mathrm{~L}^{-1}$ 盐酸, $60^{\circ} \mathrm{C}$ 水浴震荡, 反应 $3 \mathrm{~h}$, 除去碳酸盐. 然后, 以 5000 转/分的速度离心 $5 \mathrm{~min}$, 倒出上层酸液后清洗样品至少 3 次, 每次加入去离子 水约 $40 \mathrm{~mL}$, 震荡约 $30 \mathrm{~min}$ 后离心, 至上层清液的 $\mathrm{pH}$ 值 接近于 7 时结束. 最后, 把清洗好的样品 $40^{\circ} \mathrm{C}$ 低温烘干 并再次研磨成粉末, 称取约 $10 \mathrm{mg}$ 用铝箔纸包裹, 等待 上机测样. 为了消除由于去除碳酸盐带来的质量损失 而造成的误差, 这里根据所测得的碳酸盐含量对每个 样品均进行了还原计算。

蛋白石分析采用Mortlock和Froelich(1989)提出的 硅钼蓝比色法, 系统误差小于 $3 \%$. 首先称取 $0.15 \mathrm{~g}$ 烘干 研磨成粉末的沉积物样品, 置于 $30 \mathrm{~mL}$ 离心管中, 加入 $5 \mathrm{~mL} 30 \%$ 双氧水, 超声震荡 $60 \mathrm{~min}$ 以除去有机质. 然后 加入 $5 \mathrm{~mL} 1 \mathrm{~mol} \mathrm{~L}^{-1}$ 盐酸超声振荡 $30 \mathrm{~min}$, 除去碳酸盐. 离心倒出上清液烘干, 准确加入 $30 \mathrm{~mL} 2 \mathrm{~mol} \mathrm{~L}^{-1}$ 碳酸钠 溶液, 超声分散 $60 \mathrm{~min}$ 后, $85^{\circ} \mathrm{C}$ 水浴 $5 \mathrm{~h}$ 提取生物硅. 再 次离心后, 提取上清液与钼酸铵溶液反应生成硅钼黄, 而后加入 $2 \%$ 抗坏血酸溶液产生硅钼蓝. 最后用紫外 分光光度计对溶液进行测试获得吸光度, 根据标准曲 线, 通过回归方程计算沉积物中蛋白石的百分含量.

三个研究岩芯沉积物的年龄框架根据氧同位素 和碳酸盐的旋回变化结合 $\mathrm{AMS}^{14} \mathrm{C}$ 测年获得. 陆坡下 部MD12-3434岩芯采的年龄模式由高分辨的浮游有孔 虫 G. ruber氧同位素结合 $\mathrm{AMS}^{14} \mathrm{C}$ 测年数据建立(王星 星, 2015)(图2), 其底部年龄为 $78 \mathrm{ka} \mathrm{BP}$, 沉积速率平均 为 $10.8 \mathrm{~cm} \mathrm{ka}^{-1}$. 陆坡上部MD12-3428和中部MD12-3433 两个岩芯使用碳酸盐地层的年龄模式. 大量研究证实 南海的碳酸盐曲线, 在碳酸盐溶跃面以上与全球 $\delta^{18} \mathrm{O}$ 曲线变化趋势基本一致, 呈现典型的“大西洋型”碳酸 盐旋回(Wang等, 1995; 汪品先等, 1998). 而南海现代 碳酸盐溶跃面大约在 $3000 \mathrm{~m}$ (张江勇等, 2015). 这样, 对 于位于碳酸盐溶跃面之上的MD12-3428和MD12-3433 两个岩芯, 依据“大西洋型”碳酸盐旋回模式, 通过对 比三个研究岩芯X射线荧光扫描测得的钻元素相对含 量变化趋势, 同时辅以 $\mathrm{AMS}^{14} \mathrm{C}$ 测年数据作为年龄框架 的主要控制点(刘晶晶, 2015; 王星星, 2015; 施江南, 


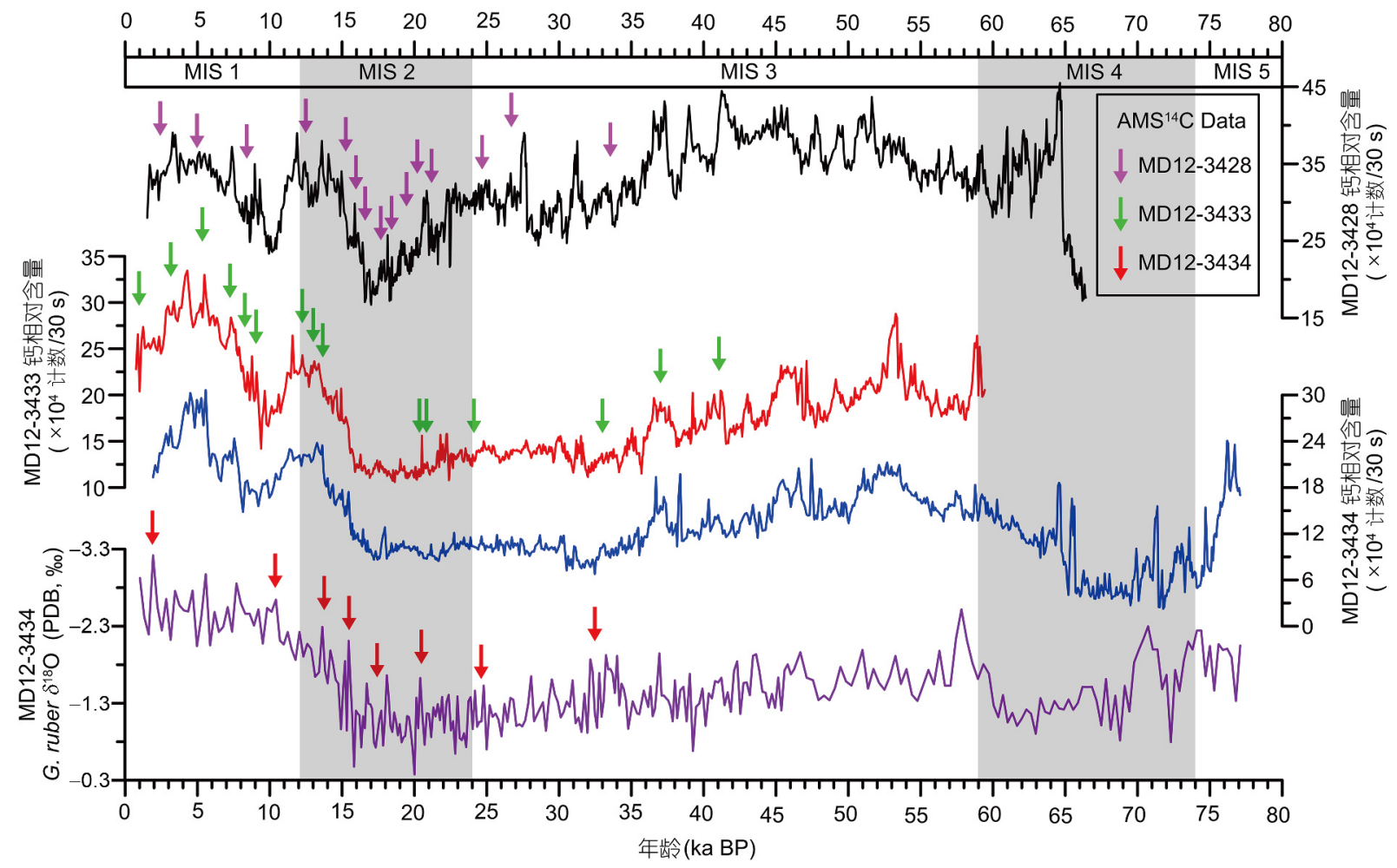

图 2 南海北部MD12-3428、MD12-3433和MD12-3434三个研究岩芯的年龄模式

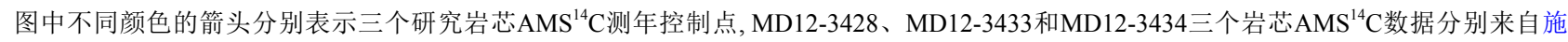
江南(2016)、刘晶晶(2015)和王星星(2015). MD12-3434岩芯G. ruber $\delta^{18} \mathrm{O}$ 曲线据王星星(2015). 浅绿色阴影表示氧同位素偶数期次, 本文中 所有涉及图件均相同

2016)(图2), 利用AnalySeries软件完成高分辨率的年龄 模式调谐. 结果显示, MD12-3428和MD12-3433两个岩 芯的底部年龄分别为 68 和 $60 \mathrm{ka} \mathrm{BP}$, 沉积速率的平均值 分别为 15.0 和 $13.8 \mathrm{~cm} \mathrm{ka}^{-1}$.

\section{3 结果}

\section{1 深海沉积物主要成分}

末次冰期以来, 陆坡上部MD12-3428岩芯沉积物 中陆源碎屑、碳酸盐、蛋白石和有机质含量的变化范 围分别为59 82\%、15 38\%、1.6 2.9\%和0.7 1.4\%, 平 均值依次为 $69 \% 、 28 \% 、 2.1 \%$ 和 $0.9 \%$ (图3, 表1). 中部 MD12-3433岩芯沉积物中陆源碎屑、碳酸盐、蛋白石 和有机质含量的变化范围分别为59 78\%、15 35\%、 $2.5 \sim 9.4 \%$ 和 $0.7 \sim 1.6 \%$, 平均值依次为 $73 \%$ 、 $20 \%$ 、 $5.6 \%$ 和 $1.1 \%$ (图3, 表1). 而下部MD12-3434岩芯沉积物中陆 源碎屑、碳酸盐、蛋白石和有机质含量的变化范围 分别为 $67 \sim 89 \% 、 6 \sim 28 \% 、 3.4 \sim 7.3 \%$ 和 $0.7 \sim 1.5 \%$, 平均
值依次为 $78 \% 、 16 \% 、 5.3 \%$ 和 $1.0 \%$ (图3, 表 1$)$. 整体上， 陆坡断面上深水沉积物主要由陆源碎屑(59 89\%)和 碳酸盐(6 38\%)组成, 二者之和一般大于 $90 \%$, 而蛋白 石(1.6 9.4\%)和有机质 $(0.7 \sim 1.9 \%)$ 的含量很低. 末次冰 期以来, 四种主要成分含量的比较中, 陆源碎屑、蛋 白石和有机质含量的时间序列变化趋势相似, 与碳酸 盐含量反向变化(图3). 其中, 陆源碎屑和碳酸盐含量 的时间序列变化均呈现明显的冰期-间冰期旋回变化, 冰期时陆源碎屑含量增加、碳酸盐含量降低, 间冰期 时则相反, 陆源碎屑减小、碳酸盐含量增加. 而蛋白 石和有机质则显示不太严格的冰期-间冰期旋回变化 (MD12-3428岩芯有机质除外), 仅在MIS 2期时呈现显 著增加趋势, 其他时期相对比较稳定.

\section{2 沉积物堆积速率}

末次冰期以来, 三个研究岩芯MD12-3428、MD123433和MD12-3434岩芯沉积物DBD的变化范围分别为 $0.74 \sim 0.97 、 0.49 \sim 0.68$ 和 $0.41 \sim 0.68 \mathrm{~g} \mathrm{~cm}^{-3}$, 平均值依次为 


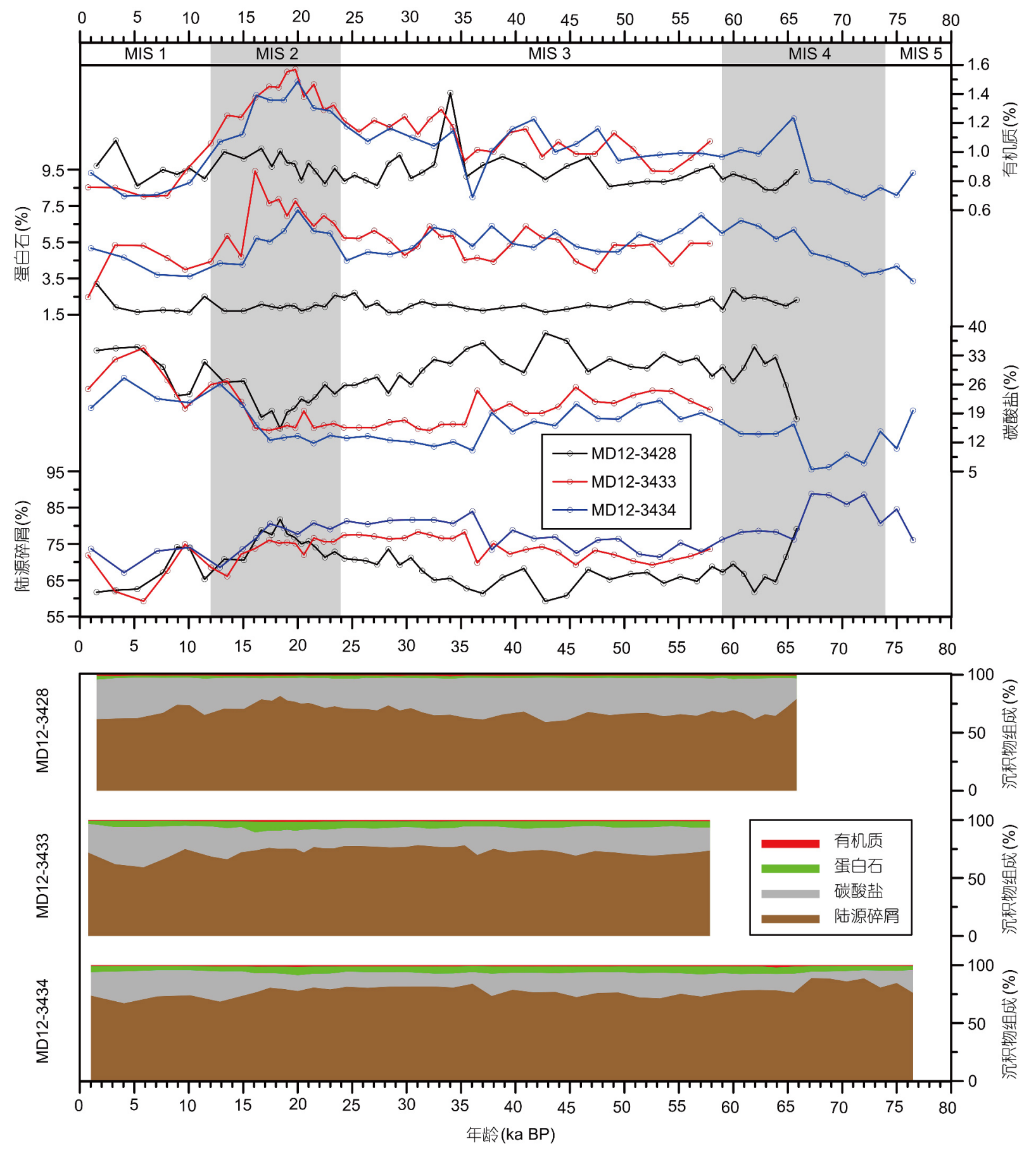

图 3 三个研究岩芯末次冰期以来的陆源碎屑、碳酸盐、蛋白石和有机质组成

上图为四种主要成分的时间序列变化; 下图为三个岩芯的四种主要成分含量的相对变化

0.87、0.58和 $0.57 \mathrm{~g} \mathrm{~cm}^{-3}$ (图 4, 表2). 根据公式(1)计算 获得的沉积物总 MAR变化范围为4.8 21.8、3.1 9.7 和 $2.4 \sim 6.8 \mathrm{~g} \mathrm{~cm}^{-2} \mathrm{ka}^{-1}$, 平均值为 $11.8 、 6.4$ 和 $4.9 \mathrm{~g} \mathrm{~cm}^{-2}$ $\mathrm{ka}^{-1}$ (图4, 表2). 三个岩芯沉积物的MAR自末次冰期以
来的时间变化趋势基本一致, 均显示一定的冰期-间 冰期旋回变化, 以陆坡上部MD12-3428岩芯最为显著 (图4). 冰期时, 三个岩芯MAR均有不同程度的增加; 间冰期时, MAR数值整体上减小, 但在某些时期也会 
表 1 三个研究岩芯末次冰期以来沉积物各成分变化范围及平均值

\begin{tabular}{cccccc}
\hline 岩芯编号 & 成分 & 碳酸盐(\%) & 蛋白石 $(\%)$ & 有机质 $(\%)$ & 陆源碎屑 $(\%)$ \\
\hline \multirow{3}{*}{ MD12-3428 } & 最大值 & 38 & 2.9 & 1.4 & 82 \\
& 最小值 & 15 & 1.6 & 0.7 & 59 \\
& 平均值 & 28 & 2.1 & 0.9 & 69 \\
\hline \multirow{3}{*}{ MD12-3433 } & 最大值 & 35 & 9.4 & 1.6 & 78 \\
& 最小值 & 15 & 2.5 & 0.7 & 59 \\
\hline \multirow{3}{*}{ MD12-3434 } & 平均值 & 20 & 5.6 & 1.1 & 73 \\
& 最大值 & 28 & 7.3 & 1.5 & 89 \\
& 最小值 & 6 & 3.4 & 0.7 & 67 \\
& 平均值 & 16 & 5.3 & 1.0 & 78 \\
\hline
\end{tabular}

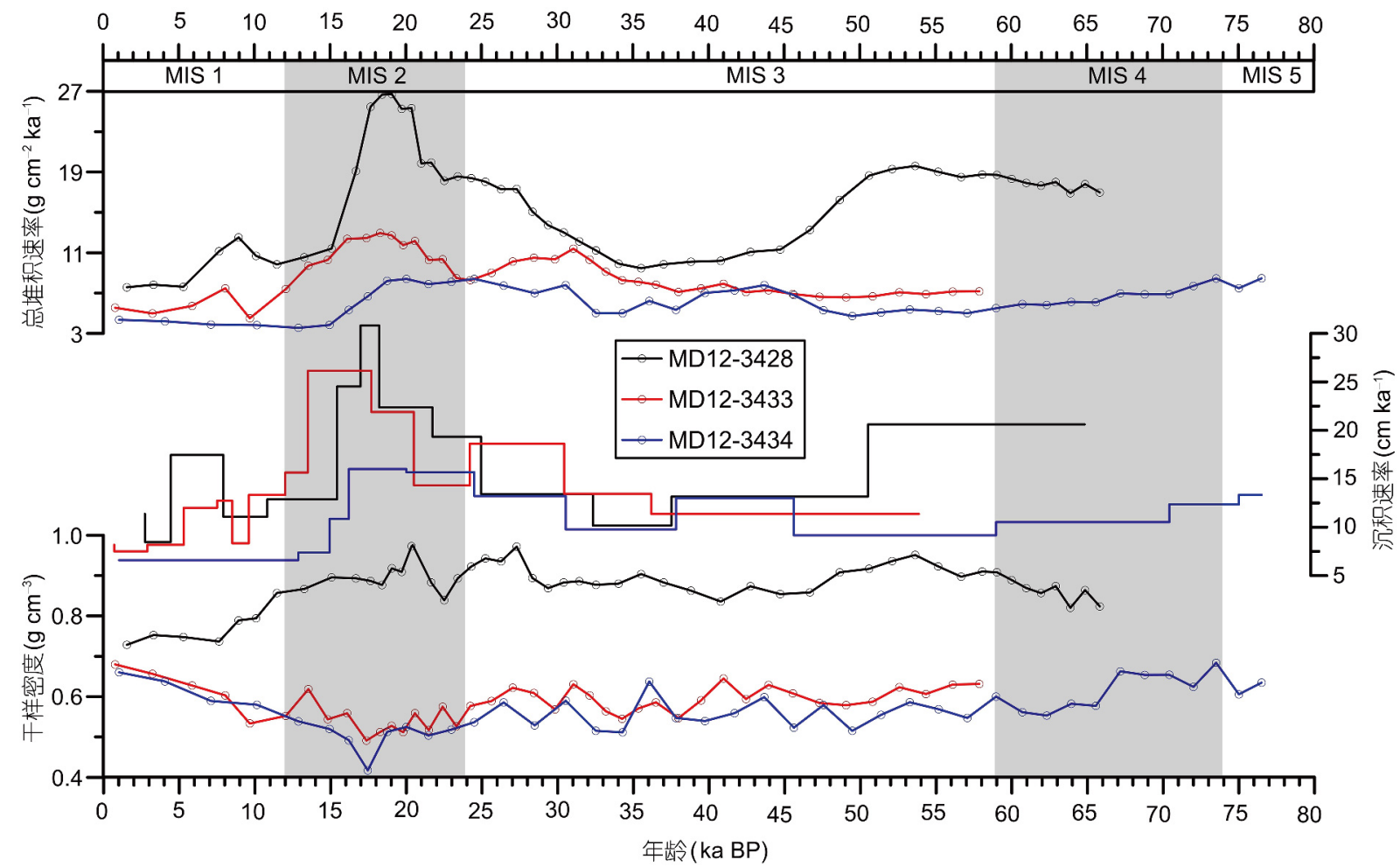

图 4 三个研究岩芯末次冰期以来的干样密度、沉积速率以及堆积速率

相对增加, 以MIS 3晚期的MD12-3433和MD12-3434两 个岩芯和全新世10 7ka BP期间的MD12-3428岩芯比 较显著.

根据公式(2)计算, 可获得南海北部深海沉积物各 成分的堆积速率. 陆坡上部MD12-3428岩芯陆源碎屑、 碳酸盐、蛋白石和有机质堆积速率的变化范围分别 为4.8 21.8、2.5 6.5、0.13 0.54和0.06 0.27 $\mathrm{g} \mathrm{cm}^{-2} \mathrm{ka}^{-1}$, 平均值依次为 $11.8 、 4.4 、 0.33$ 和 $0.14 \mathrm{~g} \mathrm{~cm}^{-2} \mathrm{ka}^{-1}$ (图5, 表
2). 而陆坡中部MD12-3433岩芯陆源碎屑、碳酸盐、 蛋白石和有机质的堆积速率分别在3.1 9.7、0.9 2.6、 0.14 1.12和0.04 0.20 $\mathrm{g} \mathrm{cm}^{-2} \mathrm{ka}^{-1}$ 范围内变化, 平均值依 次为 $6.4 、 1.7 、 0.51$ 和 $0.10 \mathrm{~g} \mathrm{~cm}^{-2} \mathrm{ka}^{-1}$ (图5, 表2). 陆坡 下部MD12-3434陆源碎屑、碳酸盐、蛋白石和有机质 的堆积速率则分别在 $2.4 \sim 6.8 、 0.4 \sim 1.7 、 0.14 \sim 0.61$ 和 $0.03 \sim 0.13 \mathrm{~g} \mathrm{~cm}^{-2} \mathrm{ka}^{-1}$ 的范围内变化, 平均值依次为4.9、 $0.90 、 0.33$ 和 $0.07 \mathrm{~g} \mathrm{~cm}^{-2} \mathrm{ka}^{-1}$ (图 5, 表2). 末次冰期以来, 
表 2 三个研究岩芯末次冰期以来沉积物干样密度及堆积速率的变化范围及平均值

\begin{tabular}{|c|c|c|c|c|c|c|c|}
\hline \multicolumn{2}{|c|}{ 岩芯编号 } & $\begin{array}{c}\text { 干样 } \\
\text { 密度 } \\
\left(\mathrm{g} \mathrm{cm}^{-3}\right)\end{array}$ & $\begin{array}{c}\text { 沉积物总 } \\
\text { 堆积速率 } \\
\left(\mathrm{g} \mathrm{cm}^{-2} \mathrm{ka}^{-1}\right)\end{array}$ & $\begin{array}{c}\text { 陆源碎屑 } \\
\text { 堆积速率 } \\
\left(\mathrm{g} \mathrm{cm}^{-2} \mathrm{ka}^{-1}\right)\end{array}$ & $\begin{array}{c}\text { 碳酸盐 } \\
\text { 堆积速率 } \\
\left(\mathrm{g} \mathrm{cm}^{-2} \mathrm{ka}^{-1}\right)\end{array}$ & $\begin{array}{c}\text { 蛋白石 } \\
\text { 堆积速率 } \\
\left(\mathrm{g} \mathrm{cm}^{-2} \mathrm{ka}^{-1}\right)\end{array}$ & $\begin{array}{c}\text { 有机质 } \\
\text { 堆积速率 } \\
\left(\mathrm{g} \mathrm{cm}^{-2} \mathrm{ka}^{-1}\right)\end{array}$ \\
\hline \multirow{3}{*}{ MD12-3428 } & 最大值 & 0.97 & 26.7 & 21.8 & 6.5 & 0.54 & 0.27 \\
\hline & 最小值 & 0.74 & 7.6 & 4.8 & 2.5 & 0.13 & 0.06 \\
\hline & 平均值 & 0.87 & 15.8 & 11.3 & 4.4 & 0.33 & 0.14 \\
\hline \multirow{3}{*}{ MD12-3433 } & 最大值 & 0.68 & 13.0 & 9.7 & 2.6 & 1.17 & 0.20 \\
\hline & 最小值 & 0.49 & 4.5 & 3.1 & 0.9 & 0.14 & 0.04 \\
\hline & 平均值 & 0.58 & 8.6 & 6.4 & 1.7 & 0.51 & 0.10 \\
\hline \multirow{3}{*}{ MD12-3434 } & 最大值 & 0.68 & 8.5 & 6.8 & 1.7 & 0.61 & 0.13 \\
\hline & 最小值 & 0.42 & 3.6 & 2.4 & 0.4 & 0.14 & 0.03 \\
\hline & 平均值 & 0.57 & 6.3 & 4.9 & 0.9 & 0.33 & 0.07 \\
\hline
\end{tabular}

南海北部深海沉积物各成分堆积速率以陆源碎屑堆 积速率最高, 碳酸盐堆积速率次之, 再次为蛋白石堆 积速率, 有机质堆积速率最小; 前二者数值大小在同 一数量级, 比后二者分别高出约 1 个和 2 个数量级(图 5 , 表2). 其中, 陆源碎屑、蛋白石和有机质的堆积速 率显示一定的冰期-间冰期旋回变化特征, 但并不严 格. 间冰期时, 陆源碎屑、蛋白石和有机质的堆积速 率均有不同程度的减小; 而冰期时, 则仅在MIS 2 期增 加显著. 而碳酸盐堆积速率的时间变化趋势则相对比 较独立且最为复杂, 陆坡上部MD12-3428站位在65 50 和27 17ka BP期间显著增加, 中部MD12-3433站位仅 在MIS 2期呈现明显增加趋势, 而下部MD12-3434站位 整体上变化相对平缓, 基本上在平均值上下浮动.

\section{4 讨论}

\section{1 深海沉积物成分及堆积速率变化与水深的关 系}

末次冰期以来, 南海北部陆坡深水断面上沿着水 深增加的方向, 无论是深海沉积物结构, 还是各成分堆 积速率, 在不同地质时期都显示了明显不同的空间递 变特征. 首先, 从沉积物成分结构上来看, 随着水深的 增加, 陆源碎屑含量整体上显著增加(三个岩芯的平均 值从 $69 \%$ 到 $73 \%$, 再到 $78 \%$ ), 碳酸盐含量相对减少(平 均值从 $28 \%$ 到 $20 \%$, 再到 $16 \%$ ), 蛋白石和有机质含量则 呈现先增加、后相对稳定的变化趋势(图3). 然而, 具 体到不同地质时期, 深水沉积物成分结构特征又随着
水深增加而发生一定改变. 冰期时, 三个研究岩芯沉 积物相同成分的含量大小及时间变化趋势呈现出趋 同性; 间冰期时, 则主要体现差异性, 以陆源碎屑和碳 酸盐含量表现最为显著. 在MIS 3 期和全新世中晚期, 同时期陆源碎屑含量随着水深的增加而呈现递增趋 势, 碳酸盐则明显递减. 而在20 8ka BP这段时期内 (末 次冰消期至全新世早期), 三个研究岩芯陆源碎屑和碳 酸盐含量及变化趋势却几乎相同. 整体上来看, 陆坡 中部MD12-3433站位和下部MD12-3434站位沉积物各 成分的时间变化趋势相似, 数值大小相近, 与陆坡上 部MD12-3428站位相差较大, 说明陆坡断面上浅水区 沉积物成分结构波动相对较大, 而深水区则趋于稳定.

其次, 从沉积物堆积速率的变化来看, 三个研究 岩芯同时期沉积物总MAR都随着水深的增加而迅速 减小, 且三者大小之间的差值在冰期时增加, 间冰期 时则相对减小(图4). 以MIS 2期为例, 上部MD12-3428 站位沉积物总MAR最大值可达 $26.7 \mathrm{~g} \mathrm{~cm}^{-2} \mathrm{ka}^{-1}$, 而中部 MD12-3433和下部MD12-3434两个站位总MAR最大 值分别只有 13.0 和 $8.5 \mathrm{~g} \mathrm{~cm}^{-2} \mathrm{ka}^{-1}$, 此时陆坡断面上不同 站位之间MAR差值达到最大. 同时, 三个研究岩芯末 次冰期以来沉积物总MAR的数值大小波动范围, 也随 着水深的增加而减小(图4). 陆坡上部MD12-3428岩芯 MAR变化范围较大, 最大与最小值相差约3倍; 而中部 MD12-3433和下部MD12-3434两个岩芯总MAR变化范 围相对较小, 最大与最小值仅相差 1 倍左右(表2). 然 而, 当具体到不同的沉积物成分时, 它们各自堆积速 率的空间变化又显示一定的差异. 陆坡断面上随着水 


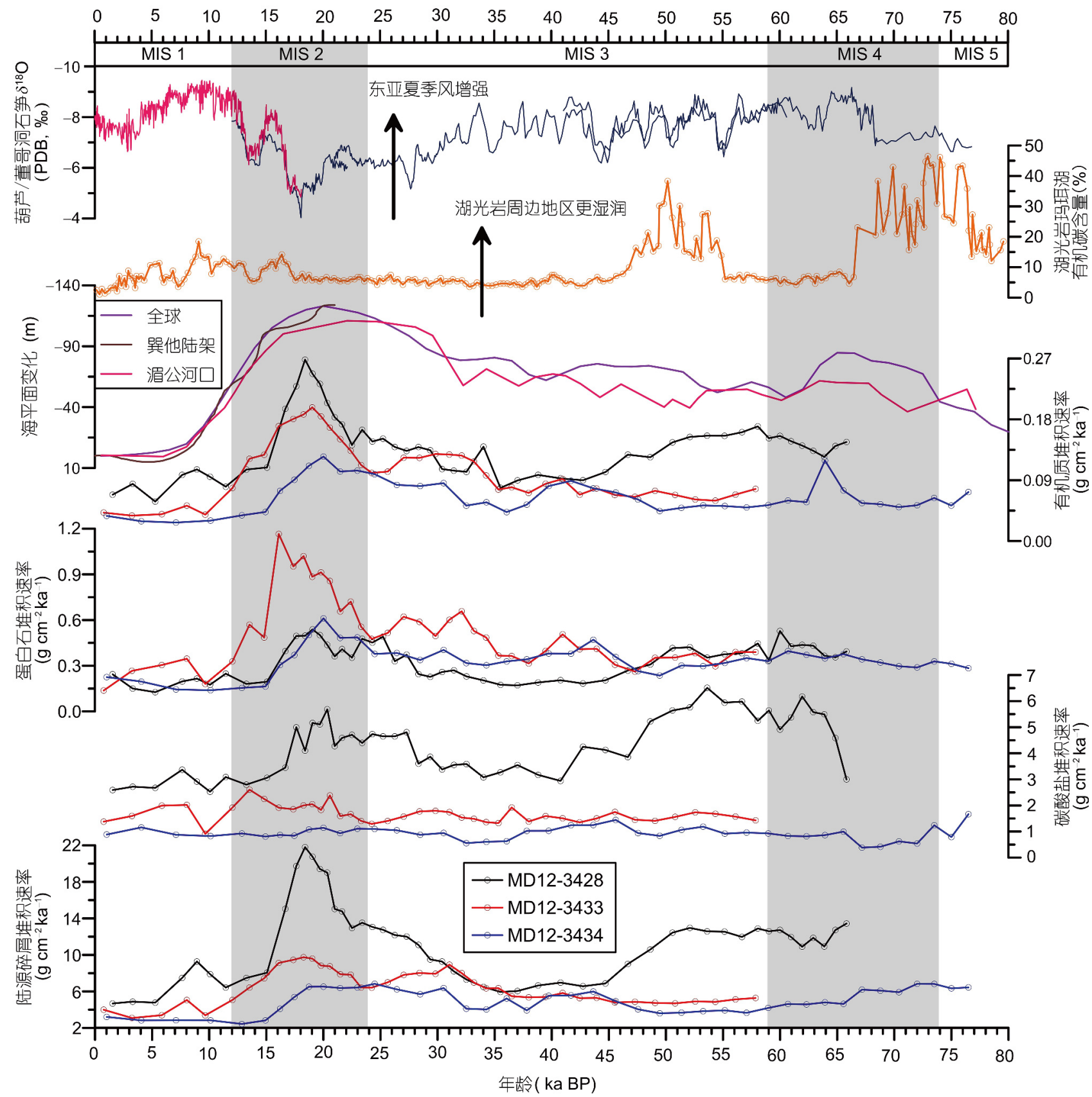

图 5 三个研究岩芯末次冰期以来沉积物各成分堆积速率的时间序列变化及其与海平面变化、湖光岩玛珥湖有机碳 含量和东亚石笋 $\delta^{18} \mathbf{O}$ 对比

全球海平面变化数据据Waelbroeck等(2002); 巽他陆架和湄公河口海平面变化数据据Hanebuth等 $(2000,2011)$; 湖光岩玛珥湖有机碳记录据 Mingram等(2004); 葫芦/董哥洞石笋氧同位素记录据Wang等(2001)和Dykoski等(2005)

加, 同时期陆源碎屑、碳酸盐和有机质堆积速率的 空间变化趋势与沉积物总 MAR一致, 均呈现减小趋 势. 而蛋白石堆积速率又显示明显的不同, 在陆坡断 面上呈现先增加后减小的变化趋势, 基本以陆坡中部

\section{MD12-3433站位数值较大.}

末次冰期以来, 对于南海北部陆坡断面上同一种 沉积物成分及其堆积速率, 也都随着水深的增加显示 了明显不同的空间递变特征, 以陆源碎屑和碳酸盐最 
为显著 (图3 和5). 随着水深的增加, 陆源碎屑含量增 加, 碳酸盐含量减少, 但二者的堆积速率均呈现减小 趋势, 且碳酸盐堆积速率的冰期-间冰期旋回变化明 显比碳酸盐含量更弱. 而对于蛋白石和有机质两种 生源成分来说, 虽然它们的百分含量及堆积速率的时 间变化趋势整体上均比较相似(MD12-3428岩芯蛋白 石含量除外)(图3和5); 但是, 陆坡断面上随着水深的 增加, 蛋白石和有机质含量及其堆积速率的大小变化 趋势也存在一定的不同之处. 一般情况下, 由陆坡上 部MD12-3428站位至中部MD12-3433站位, 蛋白石含 量及堆积速率均显示增加趋势, 有机质含量也有明显 增加, 但其堆积速率却呈现减小趋势. 再向下至深水 MD12-3434站位时, 蛋白石和有机质含量基本不变, 蛋 白石堆积速率却又显示明显的减小趋势, 有机质堆积 速率则进一步减小.

\section{2 海平面变化主控的陆源碎屑输入及其对深海 沉积物成分组成的影响}

末次冰期以来, 南海北部陆坡断面上沉积物组成 及其堆积速率主要受到海平面变化的强烈控制. 根据 前文的讨论可以看出, 南海北部陆坡断面上深水沉积 物组成及其堆积速率的空间变化特征与水深大小密 切相关, 而末次冰期以来三个研究站位水深的变化主 要由海平面的升降引起, 暗示了海平面变化对沉积物 组成及其堆积速率变化的控制作用. 南海北部具有十 分宽广的陆架, 海平面的升降旋回变化对“河流-陆架陆坡-洋盆”沉积物源汇搬运体系具有显著影响(Liu等, 2010b, 2016)(图6). 末次冰盛期时, 南海海平面平均降 低 $120 \mathrm{~m}$ (据全球以及南海南部海平面变化趋势推测, Hanebuth等, 2000, 2011; Waelbroeck等, 2002), 古珠江 口与MD12-3428、MD12-3433和MD12-3434三个研究 站位之间的距离分别缩短了约 $2 / 3 、 1 / 2$ 和 $1 / 3$ (图1). 华 南贡献的陆源碎屑更容易到达研究站位, 从而引起陆 坡断面上陆源碎屑含量及其堆积速率的显著增加, 表 现为陆源碎屑 $\mathrm{Sr}-\mathrm{Nd}$ 同位素组成和粘土矿物组合特征 明显向华南物源偏移(Liu等, 2010b, Zhao等, in review), 并且陆源碎屑颗粒大小也同时明显变粗(如Boulay等, 2007; Huang等, 2011; Liu J 等, 2016). 该时期裸露的陆 架沉积物又遭受剥蚀, 再搬运至陆坡沉积下来, 进一 步增加了陆源碎屑的输入(图6b). 同时, 陆源碎屑输入 的增加可以为生物活动带来丰富的营养盐, 又引起海
洋初级生产力的增加(陈建芳等, 1998; Ning等, 2004), 最终导致沉积物中碳酸盐、蛋白石和有机质堆积速 率也显著增加(图5). 这说明海平面变化对沉积物组成 及其堆积速率的控制作用, 主要通过改变陆源碎屑的 输入过程来实现.

末次冰期以来, 南海北部陆坡断面上三个研究岩 芯陆源碎屑含量及其堆积速率的时间序列变化, 整体 上均呈现与海平面变化相似的趋势(图5), 指示海平面 变化是控制陆源碎屑输入变化的主要原因. 冰期时, 海 平面下降, 南海北部陆源碎屑及其堆积速率迅速增加, 并在海平面最低的末次冰盛期时达到最大值. 间冰期 时, 海平面上升时, 陆源碎屑及其堆积速率则明显减 小. 陆坡断面上随着水深的增加, 海平面变化对陆源 碎屑的输入控制作用逐渐减弱. 陆坡上部MD12-3428 站位陆源碎屑含量及堆积速率的变化趋势与海平面最 为相似, 而陆坡中部MD12-3433和下部MD12-3434两 个站位陆源碎屑含量及其堆积速率与海平面变化的 相似性明显减弱, 表现为后两个岩芯陆源碎屑输入在 低海平面时期的增加量明显减小(图3和5). 即冰期时, 古珠江搬运而来的陆源碎屑物质最容易到达陆坡上部 MD12-3428站位, 其陆源碎屑含量及堆积速率的增加 幅度最大, 其次为MD12-3433站位, 最后为MD12-3434 站位(图6b). 若以高海平面时期(5 0ka BP)的陆源碎屑 堆积速率为背景值, 通过简单计算, 结果表明在MIS 2 期的低海平面时期, 三个研究岩芯的陆源碎屑堆积速 率数值由上而下依次增加约 $2.3 、 1.3$ 和 0.7 倍. 而这种 由海平面降低引起的陆源碎屑输入增加, 又间接导致 生源碎屑堆积速率的巨大变化, 以蛋白石和有机质堆 积速率的数值变化范围相对更为显著. 相对于高海平 面时期, 三个岩芯在MIS 2期碳酸盐堆积速率依次增 加 $0.6 、 0.2$ 和 0 倍, 而蛋白石和有机质堆积速率则分别 依次增加 $1.3 、 2.2 、 1.0$ 和 $1.6 、 2.8 、 1.8$ 倍.

同时, 南海北部深水陆坡上陆源碎屑输入变化与 区域季风降雨和洋流搬运也可能有一定关系. 在南海 北部, 陆源碎屑输入主要通过河流搬运的方式入海(如 Liu等, 2003, 2010a; Boulay等, 2005; Wan等, 2007; 邵否 等, 2009), 而河流的搬运能力又受到季风降雨的强弱 控制. 当季风降雨增加时, 河流径流量的增加促使其 搬运能力得到加强, 可以向海洋输入更多的陆源碎屑, 从而导致陆源碎屑含量及堆积速率增加. 以相对高海 平面时期的全新世早期为例, 董哥洞石笋氧同位素以 
(a) 间冰期-高海平面

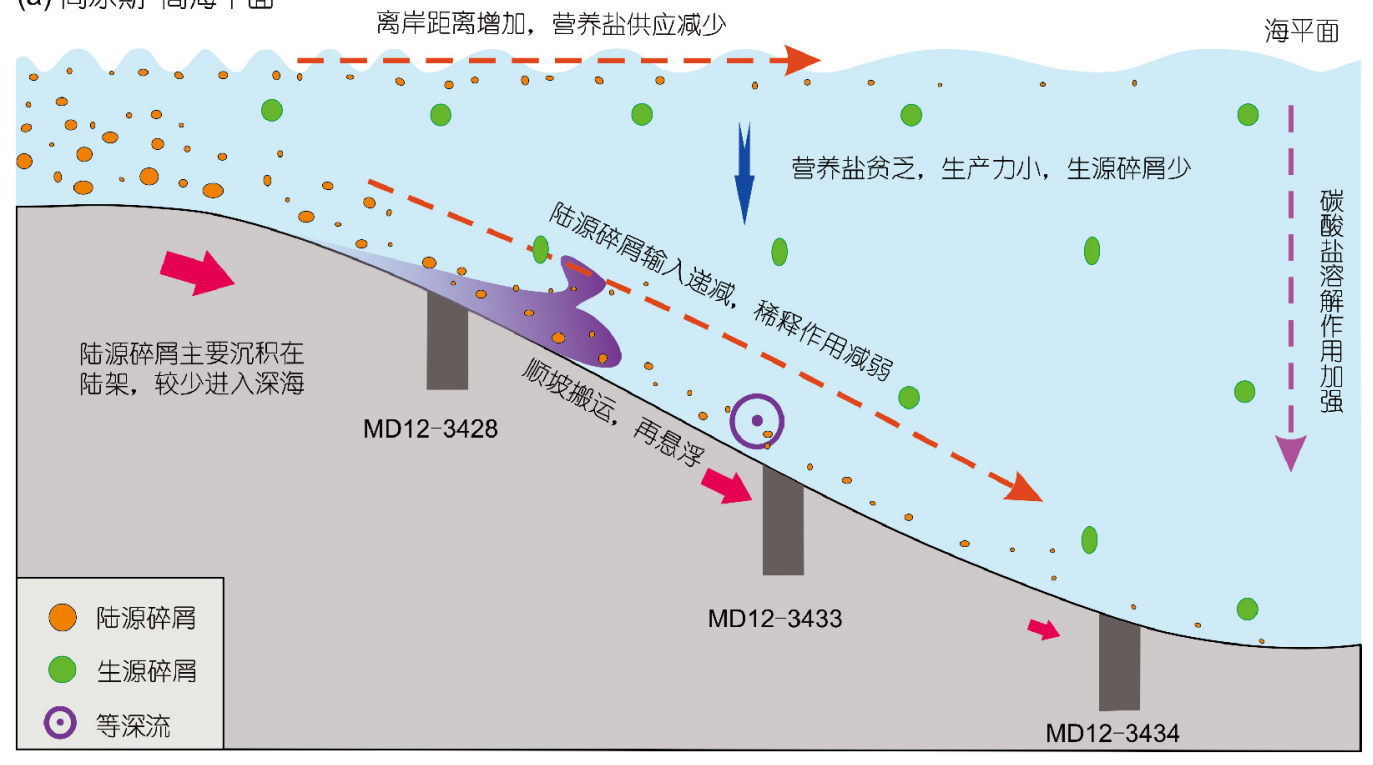

(b) 冰期-低海平面

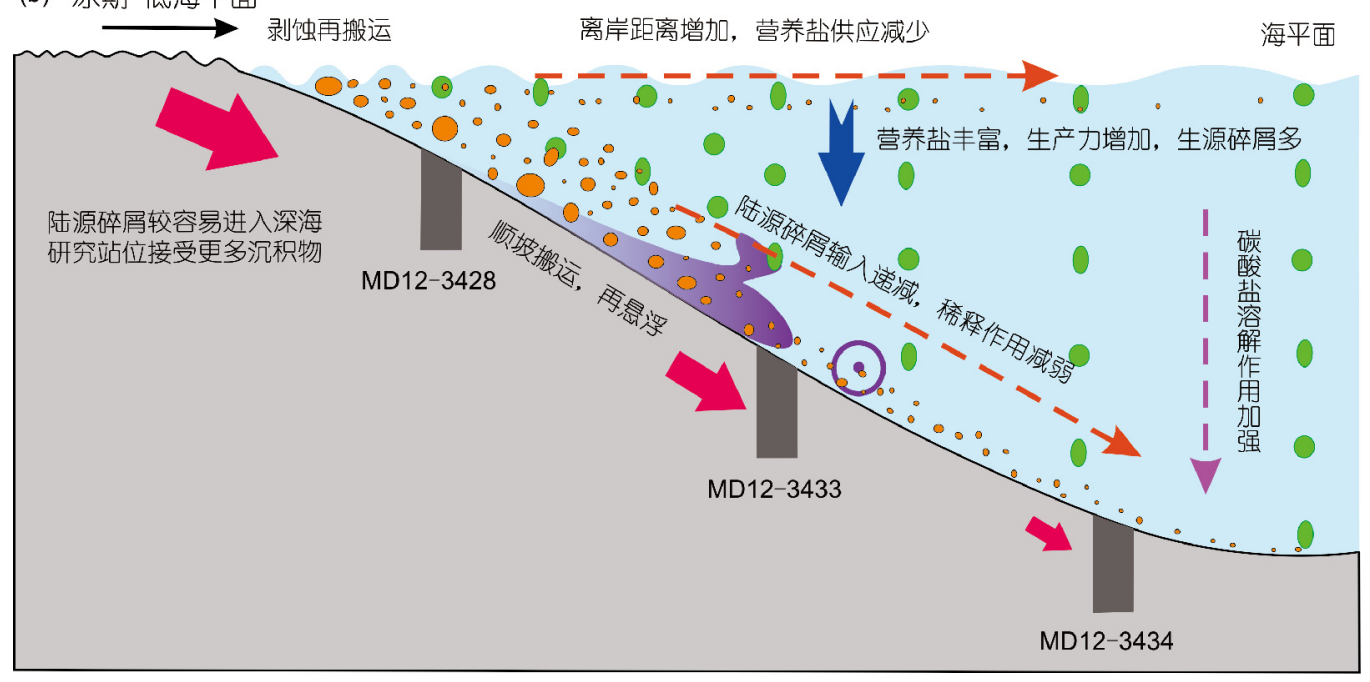

图 6 末次冰期以来陆源碎屑输入对海平面变化的响应及其对沉积物组成的控制过程示意图

及华南湖光岩玛珥湖的有机质含量记录都表明东亚 夏季风降雨增强(Fuhrmann等, 2003; Mingram等, 2004; Dykoski等, 2005)(图5), 河流搬运陆源碎屑的能力随之 变强, 陆坡上部MD12-3428和中部MD12-3433两个岩 芯记录的陆源碎屑堆积速率明显增加. 并且随着水 深的增加, 陆源碎屑堆积速率增加量依次减小, 至下 部MD12-3434站位时几乎消失, 又体现了典型的陆源 碎屑随着搬运距离的增加而减少的趋势. 但是, 这种 由气候变化引起的陆源碎屑输入变化信息若能抵达
深水沉积环境, 其信号则又可能得到放大(Zhao 等, in review), 以深水MD12-3434站位陆源碎屑堆积速率的 变化表现比较显著. 在MIS 4期时, MD12-3434站位的 陆源碎屑输入达到最大值, 但此时的海平面却并没有 降到最低, 同时湖光岩玛珥湖的有机质及孢粉记录却 表明气候相对湿润多雨(Fuhrmann等, 2003; Mingram 等, 2004)(图5) 这说明除去海平面的控制作用之外, 陆 源碎屑的输入也受到源区季风降雨变化的显著影响.

另外, 南海北部复杂的洋流系统通过对沉积物的 
搬运过程的控制, 也可能在一定程度上影响了陆坡断 面上沉积物组成及其堆积速率的时空变化特征. 现代 针系观测和沉积记录均揭示了等深流对沉积物具有较 强的搬运能力(Lüdmann等, 2005; 邵否等, 2007; Zhao 等, 2015), 而陆坡中部MD12-3433 和下部MD12-3434 两个站位恰好处在等深流影响的水深, 陆源碎屑输入 及堆积过程肯定受到等深流搬运的控制(图6). 然而, 由于南海地区关于古洋流演化的研究相对偏少, 现在 还难以准确评估洋流搬运过程对深海沉积物成分组 成及其堆积速率影响的重要性, 还需要进一步研究.

\section{3 陆源碎屑输入对生源物质的控制与稀释}

通过上述分析, 可以看出末次冰期以来海平面升 降引起的陆源碎屑输入变化, 是影响南海北部深水沉 积物组成及其堆积速率变化的主控因素. 具体来说, 陆源碎屑输入的多少, 直接决定了生物活动所需营养 盐的丰富程度, 进而改变海洋初级生产力的大小, 也 就间接控制了生源碎屑输入量的多寊, 从而影响到沉 积物的堆积过程. 同时, 陆源碎屑与生源碎屑之间又 存在明显的相互稀释作用, 进一步影响了沉积物的成 分组成. 陆源碎屑输入对生源物质的控制与稀释, 均 在冰期时表现比较显著.

末次冰期以来, 南海北部陆坡断面上三个研究岩 芯生源碎屑堆积速率受陆源碎屑输入的强烈控制, 碳 酸盐(MD12-3434岩芯除外)、蛋白石和有机质的堆积 速率均随着陆源碎屑堆积速率的增加而明显增加. 在 南海北部, 陆源碳酸盐因受湿热气候影响而几乎全部 以溶解态 $\mathrm{Ca}^{2+}$ 的形式搬运入海, 说明碳酸盐的陆源贡 献量可以忽略不计; 沉积物中有机质较小的 $\mathrm{C} / \mathrm{N}$ 比值 则指示有机质以海洋自生为主(陈建芳等, 1998; Chen, 2005; 李丽等, 2008), 而蛋白石本身就是海洋硅质生物 的骨骼. 因此, 可以认为深海沉积物中的生源碎屑全 部来自海洋, 与海洋初级生产力大小直接相关. 海洋 初级生产力的变化受到营养盐、温度、光照强度、 洋流、季风降雨、离岸距离等多种因素综合控制, 且 各种因素往往会相互牵制, 但是对于塞营养的南海地 区, 其中最根本、最关键的依然是营养盐的丰富程度 (陈建芳等, 1998; Lin等, 1999; Ning等, 2004; 李丽等, 2008). 当陆源碎屑输入在低海平面时期增加时, 营养 盐供给增加; 同时, 同步变强的东亚冬季风又引起表 层海水混合程度增加, 营养盐利用效率增加(Wei等,
1997; Liu等, 2003), 最终引起海洋初级生产力的提高, 表现为三个研究岩芯沉积物中各生源碎屑的堆积速 率均有不同程度的明显增加(图5). 当陆源碎屑输入减 小时, 营养盐供应减少, 研究站位生源碎屑堆积速率 也随之减小. 并且, 不论是低海平面的冰期, 还是高海 平面的间冰期, 陆源碎屑输入携带的营养盐在海洋表 层海水中的分布,一般都随着离岸距离(水深增加的方 向)的增加呈现递减趋势(图6). 因此, 海洋初级生产力 也会随之而递减, 导致陆坡断面上生源碎屑(以碳酸盐 为主)输入总量整体上随着水深的增加而递减, 表现在 同时期陆坡上部MD12-3428站位生源碎屑输入最大, 中部MD12-3433站位次之, 深水站位MD12-3434最少.

末次冰期以来, 南海北部陆源碎屑输入对生源碎 屑的稀释作用, 以碳酸盐最为明显, 蛋白石次之, 有机 质则基本不显示. 时间上以陆源碎屑输入显著增加 的冰期(MIS 2期) 表现最为显著, 空间上则以接受陆 源碎屑相对较多的陆坡上部比较明显. 末次冰期以 来, 三个研究岩芯碳酸盐含量由于受到陆源碎屑输入 的稀释作用, 而显示典型的“大西洋型”旋回. 冰期时, MD12-3428和MD12-3433两个岩芯的碳酸盐堆积速率 明显增加, MD12-3434岩芯则相对稳定; 但此时陆源 碎屑输入的大幅增加, 对碳酸盐形成强烈的稀释作用, 使得碳酸盐含量都达到相对低值(图3和5). 间冰期时, 陆源碎屑输入随着海平面上升而减小, 对碳酸盐的稀 释作用降低, 碳酸盐含量相对增加. 陆坡断面上随着 水深的增加, 陆源碎屑输入的递减会造成陆源碎屑对 生源碎屑稀释作用的减弱. 而碳酸盐含量及其堆积速 率随水深增加而同步递减, 可能暗示了碳酸盐溶解作 用的逐渐变强(图6), 这使得碳酸盐的旋回性变化呈现 由“大西洋型”向“太平洋型”递变的趋势, 同时也可能 是导致深水MD12-3434站位碳酸盐堆积速率在冰期时 没有显著变化的主要原因. 与碳酸盐相似, 陆源碎屑 的输入同样对蛋白石和有机质输入有较强的稀释作 用, 只是整体上的表现不甚明显, 仅在MIS 2 期陆坡上 部MD12-3428站位表现比较显著. 该时期蛋白石和有 机质堆积速率均有显著增加(图3和5), 但同时期陆源 碎屑输入大幅度增加, 稀释作用增强, 从而造成蛋白石 的含量变化并不明显, 有机质含量的增加幅度也较小.

综上所述, 陆源碎屑输入主要通过改变营养盐的 丰富程度, 来间接控制海洋初级生产力的大小, 从而达 到改变生源碎屑输入量的目的; 同时结合陆源与生源 
碎屑之间相互稀释作用的变化, 最终导致南海北部沉 积物堆积过程发生变化. 末次冰期以来, 当海平面在 冰期降低时, 河流搬运以及暴露陆架剥蚀再搬运而来 的陆源碎屑, 更容易抵达研究站位并沉积下来, 整个陆 坡断面上陆源碎屑的堆积量均有明显增加(图6b). 同 时, 营养盐供应相对丰富, 这将引起海洋初级生产力 的提高, 使得生源碎屑输入总量迅速提升; 但由于陆 源碎屑的增加幅度更大, 对生源碎屑产生强烈的稀释 作用, 却导致沉积物中生源碎屑含量的增加并不明显 甚至降低. 当海平面在冰消期迅速上升时, 陆源碎屑 输入量的减少会同步引起海洋初级生产力的降低; 即 陆源碎屑和生源物质堆积速率整体减小, 陆源碎屑的 稀释作用降低, 此时整个断面上陆源碎屑含量的差别 达到最小, 碳酸盐含量也是如此. 当海平面继续上升 至高海平面时, 如图6a所示, 整个陆坡上的陆源碎屑输 入进一步减少, 稀释作用也随之继续减弱, 生源碎屑 输入虽然也降低, 但在沉积物中的百分含量却得到增 加. 另外, 对于南海北部的深海沉积物, 不同组分堆积 速率之间还存在一个非常有意思的现象. 在空间上三 个研究站位由浅水至深水, 陆源碎屑、碳酸盐、有机 质堆积速率数值大小变化趋势相同, 均为MD12-3428 $>$ MD12-3433> MD12-3434, 但蛋白石堆积速率却是 MD12-3433>MD12-3434>MD12-3428(图5). 据推测这 可能是由于钙质与硅质生物活动相互竞争的结果, 即 在浅水区陆源碎屑输入相对较多, 营养盐丰富(图6), 钻质生物最为活跃; 当水深增加, 营养盐随陆源碎屑 输入的减少而减少时, 硅质生物活动开始增强; 而当 营养盐进一步减少时, 二者都减少. 具体情况是否如 此, 还需要在以后的研究中进行更深一步的探讨.

\section{5 结论}

本文通过对南海北部MD12-3428、MD12-3433和 MD12-3434三个岩芯末次冰期78ka BP以来沉积物的 成分分析, 研究了陆坡断面上深水沉积物组成及其堆 积速率的时空变化特征, 主要形成以下结论:

(1) 末次冰期以来, 南海北部陆坡断面上深水沉 积物主要由陆源碎屑 $(59 \sim 89 \%)$ 、碳酸盐 $(6 \sim 38 \%)$ 组 成, 含有一定量的蛋白石(1.6 9.4\%)和少量的有机质 (0.7 1.9\%). 陆源碎屑和碳酸盐的堆积速率分别达到 2.4 21.8和0.4 6.5 $\mathrm{g} \mathrm{cm}^{-2} \mathrm{ka}^{-1}$ 范围, 比蛋白石和有机质 堆积速率高出 $1 \sim 2$ 个数量级.
(2) 南海北部陆坡深水沉积物各成分及其堆积速 率都显示一定的冰期-间冰期旋回变化, 陆源碎屑、蛋 白石和有机质及其堆积速率在MIS 2期明显增加, 而 碳酸盐的含量及其堆积速率变化则呈反向变化或增 幅不明显. 陆坡断面上随着水深增加, 相同地质时期 的陆源碎屑含量增加, 但其堆积速率递减; 碳酸盐含 量及其堆积速率均递减, 而有机质和蛋白石的含量及 其堆积速率呈现复杂的变化特征.

(3) 南海北部陆坡深水断面上沉积物组成及其堆 积速率受到海平面变化的强烈控制, 季风降雨引起的 陆源物质供给变化也有一定的影响. 它们通过控制陆 源碎屑输入量来间接控制生源碎屑输入的多少, 进而 改变陆源与生源碎屑相互稀释作用的强弱, 最终实现 对沉积物堆积过程的调控. 低海平面时期, 陆源碎屑 更易搬运至陆坡深水区, 并带来丰富的营养盐, 使得 海洋初级生产力增加, 生源碎屑输入随之增加. 同时, 陆源碎屑的稀释作用增强, 导致沉积物中生源碎屑含 量降低. 而在高海平面时期, 陆源碎屑输入减小, 稀释 作用减弱, 生源碎屑输入也随之减少, 其含量却显著 增加.

致谢本次研究所用样品由中法合作“MD190CIRCEA"(Circulation in East Asian Seas)航次提供, 在样 品有机质和蛋白石分析过程中分别得到了温珂、杨禄 和黄梦雪等同学的热心帮助, 在此一并致谢. 同时感谢 两位审稿人对此文提出的大量建设性意见.

\section{参考文献}

陈建芳, 郑连福, Wiesner G, 陈荣华, 郑玉龙, Wong H. 1998. 基于沉 积物捕获器的南海表层初级生产力及输出生产力估算. 科学通 报, 43: 639-641

黄维, 汪品先. 1998. 末次冰期以来南海深水区的沉积速率. 中国科 学 D辑: 地球科学, 28: 13-17

黄维, 汪品先. 2007. 南海深水区末次冰期和冰后期沉积物堆积速 率的特征. 海洋学报, 29: 69-73

李建如, 王汝建, 李保华. 2002. 南海南部12 Ma以来的蛋白石堆积 速率与古生产力变化. 科学通报, 47: 235-237

李丽, 王慧, 罗布次仁, 贺娟. 2008. 南海北部4万年以来有机碳和 碳酸盐含量变化及古海洋学意义. 海洋地质与第四纪地质, 28 : $79-85$

刘晶晶. 2015. 末次冰期以来南海北部及相邻陆区降雨和植被变化. 硕士学位论文. 上海: 同济大学 
邵否, 李学杰, 耿建华, 庞雄, 雷永昌, 乔培军, 王嘹亮, 王宏斌. 2007. 南海北部深水底流沉积作用. 中国科学 D辑: 地球科学, 37: 771-777

郡否, 乔培军, 庞雄, 韦刚健, 李前裕, 苗卫良, 李昂. 2009. 南海北部 近代沉积物钕同位素分布及意义. 科学通报, 54: 98-103

施江南. 2016. 晚第四纪冰期旋回中南海层水的演变. 硕士学位论 文. 上海: 同济大学

汪品先. 1998. 西太平洋边缘海的冰期碳酸盐旋回. 海洋地质与第 四纪地质, 18: 1-11

汪品先. 2009. 深海沉积与地球系统. 海洋地质与第四纪地质, 29: $1-11$

汪品先. 2012. 追踪边缘海的生命史: “南海深部计划”的科学目标. 科学通报, 57: 1807-1826

王汝建, 翊知泜, 肖文申, 田军, 李建如, 陈荣华, 郭玉龙, 陈建芳. 2007. 南海第四纪的生源蛋白石记录: 与东亚季风、全球冰量 和轨道驱动的联系. 中国科学 D辑: 地球科学, 37: 521-533

王汝建, 李建. 2003. 南海ODP 1143站第四纪高分辨率的蛋白石记 录及其古生产力意义. 科学通报, 48: 74-77

王星星. 2015. 末次冰期以来南海北部的古海洋演化及其对海气 $\mathrm{CO}_{2}$ 交换的影响. 硕士学位论文. 上海: 同济大学

张江勇, 周洋, 陈芳, 高红芳, 张欣, 段淲. 2015. 南海北部表层沉积 物碳酸钻含量及主要钻质微体化石丰度分布. 第四纪研究, 35 : 1366-1382

章伟艳, 张富元, 陈荣华, 张霄宇. 2002. 南海深水区晚更新世以来 沉积速率、沉积通量与物质组成. 沉积学报, 20: 668-674

Boulay S, Colin C, Trentesaux A, Frank N, Liu Z. 2005. Sediment sources and East Asian monsoon intensity over the last $450 \mathrm{ky}$. Mineralogical and geochemical investigations on South China Sea sediments. Palaeogeogr Palaeoclimatol Palaeoecol, 228: 260-277

Boulay S, Colin C, Trentesaux A, Clain S, Liu Z, Lauer-Leredde C. 2007. Sedimentary responses to the Pleistocene climatic variations recorded in the South China Sea. Quat Res, 68: 162-172

Chen M T, Shiau L J, Yu P S, Chiu T C, Chen Y G, Wei K Y. 2003. 500000 -Year records of carbonate, organic carbon, and foraminiferal sea-surface temperature from the southeastern South China Sea (near Palawan Island). Palaeogeogr Palaeoclimatol Palaeoecol, 197: 113-131

Chen Y L. 2005. Spatial and seasonal variations of nitrate-based new production and primary production in the South China Sea. Deep Sea Res Part I-Oceanographic Res Papers, 52: 319-340

Clift P D, Wan S, Blusztajn J. 2014. Reconstructing chemical weathering, physical erosion and monsoon intensity since $25 \mathrm{Ma}$ in the northern South China Sea: A review of competing proxies. Earth-Sci Rev, 130: $86-102$

Ding W, Li J, Li J, Fang Y, Tang Y. 2013. Morphotectonics and evolutionary controls on the Pearl River Canyon system, South China Sea.
Mar Geophys Res, 34: 221-238

Dykoski C A, Edwards R L, Cheng H, Yuan D, Cai Y, Zhang M, Lin Y, Qing J, An Z, Revenaugh J. 2005. A high-resolution, absolute-dated Holocene and deglacial Asian monsoon record from Dongge Cave, China. Earth Planet Sci Lett, 233: 71-86

Fuhrmanna A, Mingram J, Lücke A, Lu H Y, Horsfield B, Liu J Q, Negendank J, Schleser G, Wilkes H. 2003. Variations in organic matter composition in sediments from Lake Huguang Maar (Huguangyan), South China during the last $68 \mathrm{ka}$ : Implications for environmental and climatic change. Org Geochem, 4: 1497-1515

Hanebuth T, Stattegger K, Grootes P M. 2000. Rapid flooding of the sunda shelf: A late-glacial sea-level record. Science, 288: 1033-1035

Hanebuth T J J, Voris H K, Yokoyama Y, Saito Y, Okuno J. 2011. Formation and fate of sedimentary depocentres on Southeast Asia's Sunda Shelf over the past sea-level cycle and biogeographic implications. Earth-Sci Rev, 104: 92-110

Huang J, Li A, Wan S. 2011. Sensitive grain-size records of Holocene East Asian summer monsoon in sediments of northern South China Sea slope. Quat Res, 75: 734-744

Kissel C, Jian Z, Leau H, and the Shipboard Scientific Party. 2012. MD190-CIRCEA cruise report. In: Les rapports de campagne à la mer, IPEV. ref: OCE/2012/01

Lin H L, Lai C T, Ting H C, Wang L, Sarnthein M, Hung J J. 1999. Late Pleistocene nutrients and sea surface productivity in the South China Sea: A record of teleconnections with Northern Hemisphere events. Mar Geol, 156: 197-210

Liu K K, Chao S Y, Shaw P T, Gong G C, Chen C C, Tang T Y. 2002. Monsoon-forced chlorophyll distribution and primary production in the South China Sea: Observations and a numerical study. Deep Sea Res Part I-Oceanographic Res Papers, 49: 1387-1412

Liu J, Xiang R, Kao S J, Fu S, Zhou L. 2016. Sedimentary responses to sea-level rise and Kuroshio Current intrusion since the Last Glacial Maximum: Grain size and clay mineral evidence from the northern South China Sea slope. Palaeogeogr Palaeoclimatol Palaeoecol, 450: $111-121$

Liu Z, Colin C, Li X, Zhao Y, Tuo S, Chen Z, Siringan F P, Liu J T, Huang C Y, You C F, Huang K F. 2010a. Clay mineral distribution in surface sediments of the northeastern South China Sea and surrounding fluvial drainage basins: Source and transport. Mar Geol, 277: 48-60

Liu Z F, Li X J, Colin C, Ge H M. 2010b. A high-resolution clay mineralogical record in the northern South China Sea since the Last Glacial Maximum, and its time series provenance analysis. Chin Sci Bull, 55: $4058-4068$

Liu Z, Trentesaux A, Clemens S C, Colin C, Wang P, Huang B, Boulay S. 2003. Clay mineral assemblages in the northern South China Sea: Implications for East Asian monsoon evolution over the past 2 million 
years. Mar Geol, 201: 133-146

Liu Z, Zhao Y, Colin C, Stattegger K, Wiesner M G, Huh C A, Zhang Y, Li X, Sompongchaiyakul P, You C F, Huang C Y, Liu J T, Siringan F P, Le K P, Sathiamurthy E, Hantoro W S, Liu J, Tuo S, Zhao S, Zhou S, He Z, Wang Y, Bunsomboonsakul S, Li Y. 2016. Source-tosink transport processes of fluvial sediments in the South China Sea. Earth-Sci Rev, 153: 238-273

Lüdmann T, Wong H, Berglar K. 2005. Upward flow of North Pacific Deep Water in the northern South China Sea as deduced from the occurrence of drift sediments. Geophys Res Lett, 32: L05614

Milliman, J, Farnsworth K. 2011. River Discharge to the Coastal Ocean: A Global Synthesis. Cambridge: Cambridge University Press

Mingram J, Schettler G, Nowaczyk N, Luo X, Lu H, Liu J, Negendank J F W. 2004. The Huguang maar lake-A high-resolution record of palaeoenvironmental and palaeoclimatic changes over the last 78000 years from South China. Quaternary Int, 122: 85-107

Mortlock R A, Froelich P N. 1989. A simple method for the rapid determination of biogenic opal in pelagic marine sediments. Deep Sea Res Part A-Oceanographic Res Papers, 36: 1415-1426

Ning X, Chai F, Xue H, Cai Y, Liu C, Shi J. 2004. Physical-biological oceanographic coupling influencing phytoplankton and primary production in the South China Sea. J Geophys Res, 109: C10005

Rea D, Janecek T. 1981. Mass-accumulation rates of the non-authigenic inorganic crystalline (eolian) component of deep-sea sediments form the western mid-Pacific mountains, Deep Sea Drilling Project Site 463. Initial Report. 653-659

Schönfeld J, Kudrass H R. 1993. Hemipelagic sediment accumulation rates in the South China Sea related to late quaternary sea-level changes. Quat Res, 40: 368-379

Waelbroeck C, Labeyrie L, Michel E, Duplessy J C, McManus J F, Lambeck K, Balbon E, Labracherie M. 2002. Sea-level and deep water temperature changes derived from benthic foraminifera isotopic records. Quaternary Sci Rev, 21: 295-305

Wan S, Li A, Clift P D, Stuut J B W. 2007. Development of the East Asian monsoon: Mineralogical and sedimentologic records in the northern South China Sea since 20 Ma. Palaeogeogr Palaeoclimatol Palaeoecol, 254: 561-582
Wan S, Li A, Clift P D, Wu S, Xu K, Li T. 2010. Increased contribution of terrigenous supply from Taiwan to the northern South China Sea since 3 Ma. Mar Geol, 278: 115-121

Wang L, Sarnthein M, Erlenkeuser H, Grimalt J, Grootes P, Heilig S, Ivanova E, Kienast M, Pelejero C, Pflaumann U. 1999. East Asian monsoon climate during the Late Pleistocene: high-resolution sediment records from the South China Sea. Mar Geol, 156: 245-284

Wang P. 1999. Response of Western Pacific marginal seas to glacial cycles: Paleoceanographic and sedimentological features. Mar Geol, 156: 5-39

Wang P, Li Q, Tian J. 2014. Pleistocene paleoceanography of the South China Sea: Progress over the past 20 years. Mar Geol, 352: 381-396

Wang P, Li Q, Tian J, He J, Jian Z, Ma W, Dang H. 2016. Monsoon influence on planktic $\delta^{18} \mathrm{O}$ records from the South China Sea. Quaternary Sci Rev, 142: 26-39

Wang P X, Prell W, Blum P. 2000. Proceedings of Ocean Drilling ProgramInitial Reports 184. Texas A\&M University, College Station, USA

Wang P, Wang L, Bian Y, Jian Z. 1995. Late Quaternary paleoceanography of the South China Sea: Surface circulation and carbonate cycles. Mar Geol, 127: 145-165

Wang Y J, Cheng H, Edwards R L, An Z S, Wu J Y, Shen C C, Dorale J A. 2001. A high-resolution absolute-dated late Pleistocene Monsoon record from Hulu Cave, China. Science, 294: 2345-2348

Wei K Y, Yang T N, Huang C Y. 1997. Glacial-Holocene calcareous nannofossils and paleoceanography in the northern South China Sea. Mar Micropaleontol, 32: 95-114

Zhang Y, Liu Z, Zhao Y, Wang W, Li J, Xu J. 2015. Mesoscale eddies transport deep-sea sediments. Sci Rep, 4: 5937

Zhao S H, Liu Z F, Colin C, Zhao Y L, Wang X X, Jian Z M. 2017. Responses of the East Asian monsoon system in the low-latitude South China Sea to millennial-scale climatic changes of high-latitudes. Paleoceanography, under review

Zhao Y, Liu Z, Zhang Y, Li J, Wang M, Wang W, Xu J. 2015. In situ observation of contour currents in the northern South China Sea: Applications for deepwater sediment transport. Earth Planet Sci Lett, 430: $477-485$ 